\title{
Analisis Pemasaran Pinang Kering Oleh Pedagang di Kecamatan Kota Kefamenanu Kabupaten Timor Tengah Utara
}

Frederikus Naimena $^{\mathrm{a}}$, dan Agustinus Nubatonis ${ }^{\mathrm{b}}$

${ }^{a}$ Fakultas Pertanian, Universitas Timor, Kefamenanu, TTU - NTT, Indonesia.

${ }^{b}$ Fakultas Pertanian, Universitas Timor, Kefamenanu, TTU - NTT, Indonesia.

\section{Article Info}

Article history:

Received in revised form 2 April 2017

Accepted 7 April 2017

\section{Keywords:}

Analisis Pemasaran

Saluran Pemasaran

Fungsi Pemasaran

Margin Pemasaran

Pinang Kering
Received 12 Maret 2017

\begin{abstract}
Abstrak
Penelitian ini bertujuan untuk mengetahui 1) saluran pemasaran pinang kering; 2) fungsi pemasaran; dan 3) margin pemasaran pinang kering di Kecamatan Kota Kefamenanu kabupaten Timor Tengah Utara yang dilaksanakan pada bulan September 2016 sampai bulan Februari 2017. Metode analisis data yang digunakan adalah metode deskripsi kualitatif dan analisis margin pemasaran. Hasil penelitian menunjukkan terdapat dua saluran pemasaran pinang kering di Kecamatan Kota Kefamenanu yakni saluran I: Pedagang Besar $\rightarrow$ Pengecer $\rightarrow$ Konsumen; dan saluran II: Pedagang Besar $\rightarrow$ Konsumen. Fungsi yang dilakukan oleh Pedagang Besar adalah fungsi penjualan dan fungsi penyimpanan, pengangkutan, penyediaan dana, penanggung risiko, dan informasi pasar, sedangkan fungsi yang dilakukan oleh pedagang Pengecer yaitu fungsi pembeli, penjualan, penyimpanan, pengangkutan, standarisasi dan grading, penanggung risiko, informasi pasar, dan penyediaan dana. Margin total pada tingkat Pedagang Besar sebesar Rp. 9.000/kg (44.4\%), sedangkan margin total Pengecer sebesar Rp. 20,000/kg (0,33\%). Hal ini menunjukkan bahwa selisih antara harga beli dengan harga jual Pedagang Besar lebih besar dari selisih harga beli dan harga jual oleh lembaga Pengecer. Karena dalam margin pemasaran terdapat dua komponen yaitu komponen biaya dan komponen keuntungan, maka yang disumbangkan oleh komponen biaya adalah untuk Pedagang Besar sebesar Rp. 40.000/kg (0,23\%), untuk Pengecer sebesar Rp.60.000/kg (2,18\%) dan Rp.5000/tumpuk (181,81\%). Hal ini menunjukkan bahwa biaya yang dikeluarkan oleh Pedagang Besar lebih besar dari pada pedagang Pengecer. Margin pemasaran terbesar untuk pinang kering terdapat pada saluran I yaitu Rp. 9.000 dengan persentase (44.44\%). (2017 dipublikasikan oleh Agrimor.
\end{abstract}

\section{Pendahuluan}

Pemasaran adalah konsep sosial dan manajerial yang membuat individu dan kelompok memperoleh apa yang mereka butuh serta inginkan lewat penciptaan dan pertukaran timbal balik produk dan nilai dengan orang lain. Sedangkan pasar adalah salah satu dari bagian sistem, institusi, prosedur dan hubungan sosial dimana usaha menjual barang, jasa dan tenaga untuk orang- orang dengan imbalan uang. Pemasaran yang baik adalah pemasaran yang terlebih dahulu mengenal Konsumen dan mengetahui bagaimana perkembangan konsep pemasaran, sebagai sebuah subjek yang sangat penting, karena dapat menentukan hidup atau matinya produk yang di pasarkan, laku atau tidaknya barang dan jasa yang ditawarkan produsen (Kotler, 2000).

Tanaman pinang (Areca catehu L.) merupakan tanaman tahunan yang sudah sangat dikenal oleh masyarakat akibat penyebaran secara alaminya cukup luas di berbagai daerah. Pinang memiliki banyak manfaat, namun, saat ini banyak masyarakat hanya mengenal pinang sebagai tanaman yang bermanfaat untuk bahan makan sirih saja, padahal masih banyak manfaat lain antara lain sebagai tanaman penghijau, bahan bangunan, bahan ramuan tradisional, bahan baku industri kosmetik, kesehatan dan bahan pewarna pada industri tekstil (Lutony, 1993).

Indonesia menjadi produsen utama pinang dunia dengan produksi yang terus meningkat setiap tahun dan mencapai 100.000 ton pada tahun 2006. Permintaan untuk ekspor juga terus meningkat. Negara tujuan ekspor saat ini meliputi Pakistan, Nepal, Banglades, India, Singapura dan Thailand (Anonim, (2006) cit. Maskromo, (2007)). Ini menunjukkan bahwa pinang dapat menjadi komoditi yang sangat menjanjikan.

Di kabupaten Timor Tengah Utara (TTU), buah pinang oleh masyarakat digunakan sebagai konsumsi atau salah satu campuran orang makan sirih (mam), yang digabungkan antara sirih, pinang, dan kapur, yang sudah melekat dengan budaya sejak dulu sampai sekarang. Pinang juga salah satu hidangan (lo'e) pada acara adat, acara pernikahan, maupun acara-acara lainya yang berhubungan dengan kebudayaan dan adat istiadat masyarakat.

Kecamatan kota Kefamenanu merupakan salah satu kecamatan yang berada di pusat kabupaten Timor Tengah Utara yang memiliki jumlah penduduk terbanyak di kabupaten TTU. Menurut data BPS Kab. TTU, (2015) jumlah penduduk kecamatan Kota Kefamenanu pada tahun 2014 sebanyak 42.321 (jiwa) dengan 8.625 kepala keluarga (KK). Kecamatan kota Kefamenanu memiliki dua pasar besar yakni pasar lama yang berada di kelurahan Kefa Tengah dan pasar baru yang berada di Kelurahan Benpasi, kedua pasar ini beroperasi setiap hari.

Survey awal pada usaha pedagang pengumpul pinang kering (Lopo, 2016) yang telah menekuni usahanya dari tahun 2000 sampai sekarang (17 tahun) dengan modal sendiri, memberikan gambaran bahwa modal awal dalam mengembangkan usahanya sebesar Rp 5.000.000. Usahanya adalah mengumpul pinang kering dan memasarkan kembali kepada pedagang Pengecer, menggunakan dua jenis pinang yaitu pinang Super, dan pinang Batu. Kedua jenis pinang ini didatangkan dari pulau Jawa (Jawa Timur) kemudian dipasarkan kepada Pengecer yang ada di kecamatan Kota Kefamenanu. Selain itu pedagang pengumpul juga memasarkan pinang kering di beberapa pasar yang ada di kabupaten TTU seperti pasar Eban, pasar Haumeni, pasar Oe,ollo, dan pasar Maubesi.

Selama 3 tahun terakhir, pinang (pinang kering) yang didatangkan dari pulau Jawa (Jawa Timur), dan dipasarkan kepada pedagang Pengecer di kabupaten TTU sebanyak 42 ton pada tahun 2013, 70 ton pada tahun 2014, dan 98 ton pada tahun 2015. Harga setiap ton adalah Rp 31.000.000. dan dipasarkan kepada Pengecer dengan harga per kg sebesar Rp 30.000 - 40.000. sedangkan di tingkat Pengecer harga per kg sebesar Rp 60.000 - 80.000 (Lopo, 2016). Hal in menunjukkan bahwa pinang kering, yang didatangkan dari luar daerah, kemudian dipasarkan di dalam daerah dari tahun 2013 sampai 2015 mengalami peningkatan, disebabkan karena meningkatnya permintaan dan kebutuhan yang tinggi seiring dengan bertambahnya jumlah penduduk dari tahun ke tahun. Taena (2009) menggambarkan masyarakat TTU juga membeli pinang dari negara Timor Leste dalam skala kecil.

Beberapa penelitian terdahulu tentang pinang di kabupaten TTU baru terbatas mengkaji tentang aspek budidaya seperti yang dilakukan Liat, (2016) serta Nainahas \& Taolin, (2017), belum ada kajian tentang pinang dalam aspek agribisnis khususnya pada aspek pemasaran. Dengan demikian maka perlu dilakukan penelitian dengan topik analisis pemasaran pinang kering oleh pedagang di kecamatan kota Kefamenanu kabupaten TTU. Tujuan penelitian ini untuk mengetahui 1) saluran pemasaran pinang kering; 2) fungsi pemasaran; dan 3) margin pemasaran pinang kering di Kecamatan Kota Kefamenanu kabupaten TTU.

\section{Metode}

Penelitian dilaksanakan pada bulan September 2016 sampai bulan Februari 2017 pada usaha pedagang pinang kering di Kecamatan Kota Kefamenanu, Kabupaten TTU. Penentuan sampel dilakukan secara purposive sampling pada pedagang pinang kering di Kota Kefamenanu dengan jumlah sampel yang diambil sebayak 37 pedagang pinang kering. Metode pengumpulan data yang digunakan dalam penelitian ini adalah metode survey, yaitu penelitian yang dilakukan untuk memperoleh fakta-fakta atau gejala yang ada dalam mencari keterangan secara fakta, baik dengan situasi sosial, ekonomi, dan masyarakat atau daerah. Untuk menunjang kesempurnaan maka peneliti melakukan mengumpulkan data yang diperoleh dari data primer yang diperoleh dari pengamatan langsung di lapangan dan wawancara (interview) atau berkomunikasi langsung dengan pertanyaan yang telah disiapkan terlebih dahulu. Data sekunder diperoleh dari literatur pustaka dan lembaga-lembaga atau instansi yang terkait, baik instansi pemerintah maupun swasta.

Metode analisis data yang digunakan adalah 1) metode deskripsi kualitatif sesuai petunjuk Sugiyono, (2006); dan analisis margin pemasaran. Analisis margin pemasaran merupakan hasil pengurangan harga penjualan dengan harga pembelian. Margin pemasaran dapat dinyatakan sebagai penjumlahan dari biayabiaya pemasaran dan keuntungan yang diperoleh pedagang yang terlibat dan dihitung dengan rumus sesuai petunjuk Hanafiah \& Saefuddin, (1986).

\section{Hasil dan Pembahasan}

\subsection{Saluran Pemasaran Pinang Kering}

Saluran pemasaran merupakan pola-pola pemasaran yang terbentuk selama pergerakan arus komoditi pertanian dari petani produsen ke Konsumen akhir.

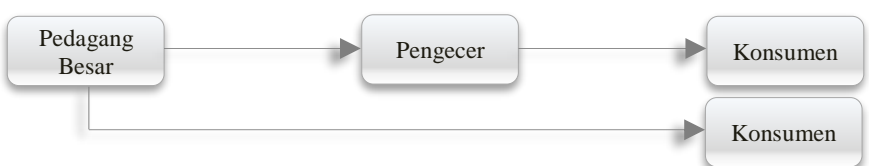

Saluran pemasaran yang terbentuk selama penyaluran pinang kering dari produksi sampai pada Konsumen akhir, ditunjukkan pada Gambar 1.

Gambar 1. Saluran Pemasaran Pinang Kering di kecamatan Kota Kefamenanu.

Berdasarkan Gambar 1. maka saluran pemasaran pinang kering di kecamatan Kota Kefamenanu dapat dijelaskan sebagai berikut:

a. Pedagang Besar $\rightarrow$ Pengecer $\rightarrow$ Komsumen

Kondisi pemasaran pinang kering pada saluran ini yakni Pedagang Besar menjual pinang kering kepada Pengecer, kemudian Pengecer menyalurkan ke 
Konsumen. Hal ini menunjukkan semakin panjang saluran yang dilalui oleh komoditi pinang kering untuk sampai ke tangan Konsumen. Dari 37 responden pedagang, 3 responden $(8,10 \%)$ yang hanya menjual kepada pedagang Pengecer, sedangkan 34 responden $(91,89 \%)$ juga menjual kepada Konsumen.

b. Pengecer $\rightarrow$ Konsumen

Kondisi pemasaran pinang kering pada saluran ini yakni pedagang Pengecer menjual pinang kering kepada Konsumen dengan harga yang bervariasi antara Rp. 50.000 - Rp. 75.000 per kg, Pengecer juga menjual secara tumpuk dengan harga Rp 5.000 per tumpuk. Dari 37 responden pedagang Pengecer, 34 responden $(91,89 \%)$ yang menjual kepada Konsumen.

\subsection{Fungsi-Fungsi Pemasaran Pinang Kering}

Fungsi-fungsi yang dilakukan oleh pedagang dalam memasarkan pinang kering kepada Konsumen di kecamatan Kota Kefamenanu maupun di pasaran lain adalah sebagaimana terlihat pada Tabel 1 .

Tabel 1. Fungsi-Fungsi Pemasaran yang Dilakukan Oleh Pedagang di Kecamatan Kota Kefamenanu.

\begin{tabular}{lccc}
\hline Fungsi-Fungsi Pemasaran & $\mathrm{P}-\mathrm{PB}$ & $\mathrm{PB}-\mathrm{PP}$ & $\mathrm{PP}-\mathrm{K}$ \\
\hline Pertukaran & & $\mathrm{V}$ & $\mathrm{V}$ \\
1. Pembeli & $\mathrm{V}$ & $\mathrm{V}$ \\
2. Penjual & $\mathrm{V}$ & & $\mathrm{V}$ \\
\hline Fisik & $\mathrm{V}$ & $\mathrm{V}$ \\
1. Penyimpanan & $\mathrm{V}$ & $\mathrm{V}$ \\
2. Pengangkutan & $\mathrm{V}$ & $\mathrm{V}$ \\
3. Paking & & \\
\hline Penyediaan Fasilitas & $\mathrm{V}$ & $\mathrm{V}$ \\
1. Grading & $\mathrm{V}$ & $\mathrm{V}$ \\
2. Risiko & $\mathrm{V}$ & $\mathrm{V}$ \\
3. Informasi Pasar & $\mathrm{V}$ & $\mathrm{V}$ \\
4. Penyediaan Dana & &
\end{tabular}

Keterangan:

$\mathrm{P}-\mathrm{PB}$ : Penjual pinang kering dari produsen kepada Pedagang Besar

PB - PP : Penjual pinang kering dari Pedagang Besar kepada Pengecer

$\mathrm{PP}-\mathrm{K}$ : Pedagang Pengecer kepada Konsumen

Fungsi-fungsi pemasaran yang dilakukan oleh pedagang pinang kering berbeda satu sama yang lain. Secara jelasnya dapat diuraikan sebagai berikut:

A. Fungsi Pemasaran Pinang Kering di Tingkat Pedagang Besar.

1) Fungsi Pertukaran

Fungsi pertukaran merupakan suatu kegiatan yang berfungsi memperlancar berpindahnya hak milik atas produk dari satu orang kepada orang lain. Rata-rata harga jual pinang kering di tingkat Pedagang Besar kecamatan Kota Kefamenanu dapat dilihat pada Tabel 2.

\section{Tabel 2. Harga Pinang Kering Tingkat Pedagang Besar}

\begin{tabular}{cc}
\hline Satuan & Harga $(\mathrm{Rp})$ \\
\hline Karung & 2.400 .000 \\
Kilogram & 40.000 \\
\hline
\end{tabular}

\section{a. Fungsi Pembelian}

Pedagang Besar membeli pinang kering dari agen (Pedagang Besar luar daerah). Proses pembelian yang dilakukan yaitu secara transaksi uang melalui Bank antara Pedagang Besar dengan Pedagang Besar luar daerah dengan harga per kilogram Rp. 31.000 atau satu ton seharga Rp. 31.000.000. Dalam satu kali transaksi sebesar 14 ton dengan harga Rp. 434.000.000.

b. Fungsi Penjualan

Fungsi penjualan yang dilakukan oleh Pedagang Besar sangat sederhana yaitu pinang kering yang dibersihkan dan dipeking (pinang Batu dan Super), dijual kepada Pengecer dan Konsumen dengan harga Rp. 30.000/kg (pinang Batu) dan Rp. 40.000/kg (pinang Super), selain itu Pedagang Besar juga mempunyai tenaga penjual, yang menjual langsung kepada Konsumen akhir dengan harga Rp. 45.000/kg (pinang Super).

\section{2) Fungsi Fisik}

Fungsi fisik meliputi kegiatan-kegiatan yang secara langsung yang diperlakukan terhadap komoditi pertanian, sehingga komoditi pertanian mengalami tambahan guna tempat, guna waktu, guna bentuk. Pinang kering yang dibeli oleh Pedagang Besar masih tercampur antara pinang Batu dan pinang Super, oleh karna itu sebelum pinang dijual terlebih dahulu dibersihkan.

a. Fungsi Penyimpanan

Proses penyimpanan pinang kering oleh Pedagang Besar sebelum dijual yakni disimpan pada tempat yang sudah disiapkan (Gudang), sebelum dipasarkan, pinang kering yang dibeli dari produsen harus dibersihkan dan dipeking dalam karung yang berukuran $50 \mathrm{~kg}$ dan $60 \mathrm{~kg}$.

\section{b. Fungsi Pengangkutan}

Proses pengangkutan pinang kering oleh Pedagang Besar mulai dari pembelian sampai proses pemasaran ditempuh dengan kendaraan roda empat (truk) milik sendiri. Fungsi ini termasuk kegiatan bongkar dan muat barang, proses pengangkutannya. Pinang kering dimuat dari Kupang ke Kefamenanu kemudian dipasarkan kepada Konsumen akhir.

\section{3) Fungsi Penyediaan Fasilitas}

Fungsi penyedia fasilitas merupakan usaha - usaha perbaikan sistem pemasaran untuk meningkatkan efisiensi operasional dan efisiensi penetapan harga. Fungsi penyedia fasilitas ini meliputi penyediaan dana atau modal yang dibutuhkan pedagang dalam memasarkan pinang kering ke tangan Konsumen, diperoleh atau bersumber dari modal sendiri (keluarga).

a. Standarisasi dan Grading

Standarisasi dan grading yang dilakukan oleh Pedagang Besar, akan selalu memperhatikan kualitas atau besar kecilnya pinang kering akan tetapi mereka akan menawarkan harga secara merata kepada Pengecer dan Konsumen dalam satuan kilogram $(\mathrm{kg})$.

b. Penanggung Risiko

Penanggung risiko tidak dialami oleh Pedagang Besar, dikarenakan mereka tidak menyimpan pinang kering dalam jangka waktu yang lama. Sedangkan untuk menghindari kerusakan Pedagang Besar menyimpan pinang pada tempat yang kering (gudang) dalam bentuk dipeking.

c. Informasi Pasar

Pada fungsi ini, hal yang paling mereka perhatikan adalah informasi harga dan penyediaan pinang kering di pasar. Informasi ini hanya dalam ruang lingkup para pedagang yaitu para produsen, Pedagang Besar, dan Pengecer saling menginformasikan mengenai penyediaan pinang kering di pasar, agar menjaga kedua belah pihak sehingga tidak mengalami kerugian.

d. Penyediaan Dana

Dalam memasarkan suatu produk, sering kali terkendala akibat kurang modal untuk melakukan transaksi-transaksi. Modal yang digunakan dalam memasarkan pinang kering adalah dari modal sendiri. Hal ini terjadi dikarenakan pedagang kawatir akan keuntungan yang diperoleh tidak memenuhi kebutuhan atau hanya kembalikan modalnya saja.

B. Fungsi Pemasaran Pinang Kering di Tingkat Pengecer

Selama pergerakan produk dari Pengecer ke Konsumen, tentu mengalami tindakan yang dilakukan oleh pedagang sehingga bisa sampai ke Konsumen. Fungsi-fungsi yang dilakukan Pengecer meliputi:

1) Fungsi Pertukaran

Rata-rata harga jual pinang kering ditingkat Pengecer dapat dilihat pada Tabel 3. Dari hasil penelitian pemasaran pinang kering dilakukan juga dalam satuan tumpuk dimana 12 tumpuk setara dengan satu kilogram.

Tabel 3. Harga Pinang Kering Tingkat Pengecer

\begin{tabular}{ccc}
\hline Satuan & Harga Beli $(\mathrm{Rp})$ & Harga Jual $(\mathrm{Rp})$ \\
\hline Kilogram & 40.000 & 60.000 \\
Tumpuk & & 5.000 \\
\hline
\end{tabular}

a. Fungsi Pembelian

Pedagang Pengecer membeli pinang kering dari Pedagang Besar dalam satuan kilogram, dengan harga rata-rata seperti yang ada pada Tabel 3. Cara pembayaran secara kontan, dan ada juga yang secara tidak kontan, (menjual dan mendapatkan hasil setelah selesai baru bayar), sistim saling percaya antara kedua bela pihak. Harga yang diberikan oleh pedagang Pengecer berkisar Rp $30.000-$ $40.000 / \mathrm{kg}$, tergantung pada kualitas pinang yang dibeli.

b. Fungsi Penjualan

Pengecer menjual pinang kering di pasar secara eceran dengan harga yang berbeda, (satuan tumpuk, ons, dan kilogram), setiap hari di lapak-lapak yang telah dibuatnya dan menjual ke langganan dengan harga rata-rata yang seperti ditunjukkan pada Tabel 3. Biaya yang dikeluarkan oleh Pengecer berupa retribusi harian Rp. 5000., transportasi Rp 10.000., dan kantong plastik Rp.10.000.

\section{2) Fungsi Fisik}

Fungsi fisik yang dijalankan berupa fungsi penyimpanan yakni penyimpanan pinang kering di tempat yang kering seperti gudang, keler, karung, dan bokor yang sudah disediakan di rumah maupun tempat penjualan (Pasar).

\section{3) Fungsi Penyediaan Fasilitas}

a. Fungsi Standarisasi dan Grading

Yang dilakukan oleh Pengecer pada fungsi ini adalah standarisasi dan grading berdasarkan $\mathrm{kg}$ dan tumpuk (dari $1 \mathrm{~kg}$ pinang kering diperoleh 12 tumpuk). Harga jual per kilogram sebesar Rp. 60.000 dan harga jual per tumpuk sebesar Rp. 5.000.

b. Informasi Pasar

Pada fungsi ini, hal yang paling mereka perhatikan adalah informasi harga dan penyediaan pinang kering di pasar. Informasi ini hanya dalam ruang lingkup para pedagang yaitu para Pedagang Besar dan Pengecer saling menginformasikan mengenai penyediaan pinang kering di pasar untuk menjaga kedua belah pihak tidak mengalami kerugian.

c. Penyediaan Dana.

Modal yang digunakan dalam memasarkan pinang kering adalah dari modal sendiri.

\subsection{Margin Pemasaran Pinang Kering}

Margin pemasaran pinang kering merupakan selisih antara harga yang dibayar oleh Konsumen dan harga yang diterima oleh produsen. Margin pemasaran terdiri atas dua komponen yaitu komponen biaya pemasaran dan komponen keuntungan lembaga pemasaran. Dilihat dari saluran pemasaran 
pinang kering di Kecamatan Kota Kefamenanu yang bervariasi, maka margin pemasaran juga sanggat bervariasi seiring dengan berbedanya saluran pemasaran pinang kering. Margin pemasaran yang terjadi pada setiap saluran pemasaran dapat dilihat pada Tabel 4

Tabel 4. Distribusi Margin Pemasaran Pinang Kering di Kecamatan Kota Kefamenanu

\begin{tabular}{|c|c|c|c|}
\hline \multirow[b]{2}{*}{ Uraian } & \multirow[b]{2}{*}{$\begin{array}{c}\text { Nilai } \\
(\mathrm{Rp} / \mathrm{kg})\end{array}$} & \multicolumn{2}{|c|}{ Distribusi Margin } \\
\hline & & $\begin{array}{c}\text { Margin } \\
\text { Total (Rp) }\end{array}$ & $\begin{array}{c}\text { Persentase } \\
\text { Margin }(\%)\end{array}$ \\
\hline \multicolumn{4}{|l|}{ Pedagang Besar } \\
\hline Harga Jual & 40.000 & \multirow{2}{*}{9.000} & \multirow{2}{*}{44,44} \\
\hline Harga Beli & 31.000 & & \\
\hline \multicolumn{4}{|l|}{ Biaya Pemasaran } \\
\hline ○ Transportasi & & 92,592 & 1,54 \\
\hline o Pengepakan & & 9.000 & 15,00 \\
\hline o Sirih, Pinang, Rokok & & 1.5000 & 2,55 \\
\hline ○ Retribusi & & 5.000 & 8,33 \\
\hline Jumlah Biaya & & 29.000 & 4,83 \\
\hline Keuntungan & & 511.000 & 5,67 \\
\hline Jumlah Margin & & 9.000 & 100,00 \\
\hline \multicolumn{4}{|l|}{ Pengecer } \\
\hline Harga Jual & 60.000 & \multirow{2}{*}{20.000} & \multirow{2}{*}{0,33} \\
\hline Harga Beli & 40.000 & & \\
\hline \multicolumn{4}{|l|}{ Biaya Pemasaran } \\
\hline - Transportasi & & 2.236 & 0,01 \\
\hline o Pengepakan & & 667 & 33,33 \\
\hline o Sirih, Pinang, Rokok & & 1667 & 83,33 \\
\hline o Retribusi & & 417 & 0,00 \\
\hline Jumlah Biaya & & 2750 & 13,75 \\
\hline Keuntungan & & 17.250 & 86,25 \\
\hline Jumlah Margin & & 20.000 & 100,00 \\
\hline
\end{tabular}

Margin total pada tingkat Pedagang Besar sebesar Rp. 9.000/kg (44.4\%), sedangkan margin total Pengecer sebesar Rp. 20,000/kg (0,33\%). Hal in menunjukkan bahwa selisih antara harga beli dengan harga jual Pedagang Besar lebih besar dari selisih harga beli dan harga jual oleh lembaga Pengecer. Karena dalam margin pemasaran terdapat dua komponen yaitu komponen biaya dan komponen keuntungan, maka yang disumbangkan oleh komponen biaya adalah untuk Pedagang Besar sebesar Rp. 40.000/kg (0,23\%), untuk Pengecer sebesar Rp.60.000/kg (2,18\%) dan Rp.5000/tumpuk (181,81\%). Hal ini menunjukkan bahwa biaya yang dikeluarkan oleh Pedagang Besar lebih besar dari pada pedagang Pengecer.

\section{Simpulan}

Saluran pemasaran pinang kering oleh pedagang di Kecamatan Kota Kefamenanu, kabupaten TTU yakni Pedagang Besar mendatangkan pinang kering dari luar daerah dengan harga setiap ton Rp 31.000.000., kemudian Pedagang Besar memasarkan pinang kering kepada Pengecer di dalam daerah

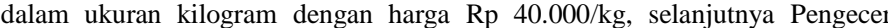
memasarkan kepada Konsumen akhir dengan ukuran kilogram (Rp 60.000/kg) dan tumpuk (Rp 5.000/tumpuk). Terdapat dua saluran pemasaran pinang kering di Kecamatan Kota Kefamenanu yakni saluran I: Pedagang Besar $\rightarrow$ Pengecer $\rightarrow$ Konsumen; dan saluran II: Pedagang Besar $\rightarrow$ Konsumen.

Fungsi yang dilakukan oleh Pedagang Besar adalah fungsi penjualan dan fungsi penyimpanan, pengangkutan, penyediaan dana, penanggung risiko, dan informasi pasar, sedangkan fungsi yang dilakukan oleh pedagang Pengecer yaitu fungsi pembeli, penjualan, penyimpanan, pengangkutan, standarisasi dan grading, penanggung risiko, informasi pasar, dan penyediaan dana.

Margin total pada tingkat Pedagang Besar sebesar Rp. 9.000/kg (44.4\%), sedangkan margin total Pengecer sebesar Rp. 20,000/kg (0,33\%). Hal ini menunjukkan bahwa selisih antara harga beli dengan harga jual Pedagang Besar lebih besar dari selisih harga beli dan harga jual oleh lembaga Pengecer. Karena dalam margin pemasaran terdapat dua komponen yaitu komponen biaya dan komponen keuntungan, maka yang disumbangkan oleh komponen biaya adalah untuk Pedagang Besar sebesar Rp. 40.000/kg (0,23\%), untuk Pengecer sebesar Rp.60.000/kg (2,18\%) dan Rp.5000/tumpuk (181,81\%). Hal ini menunjukkan bahwa biaya yang dikeluarkan oleh Pedagang Besar lebih besar dari pada pedagang Pengecer. Margin pemasaran terbesar untuk pinang kering terdapat pada saluran I yaitu Rp. 9.000 dengan persentase (44.44\%).

\section{Pustaka}

BPS Kab. TTU 2015. Timor Tengah Utara dalam Angka 2014. Kefamenanu: Badan Pusat Statistik Kabupaten TTU.

Hanafiah, A.M. \& Saefuddin, A.M. 1986. Tataniaga Hasil Pertanian. Jakarta: Universitas Indonesia Press.

Kotler, P. 2000. Manajemen Pemasaran di Indonesia: Analisis Perencanaan Implementasi dan Pengendalian. Jakarta: Salemba Empat.

Liat, H.E.K. 2016. Pengaruh Model Pemeraman dan Kondisi Cahaya terhadap Perkecambahan Benih Pinang (Areca catechu L.). Savana Cendana, 1(02): 74-76.

Lopo, D. 2016. Pemasaran Pinang di Kefamenanu.
Lutony, T.L. 1993. Pinang Sirih: Komoditi Ekspor dan Serbaguna. Jakarta: Kanisius.

Maskromo, I. 2007. Keragaman Genetik Plasma Nutfah Pinang (Areca Catechu L.) di Provinsi Gorontalo. Industrial Crops Research Journal, 13(4): 119124.

Nainahas, K.I. \& Taolin, R.I. 2017. Pengaruh Lama Perendaman Air Kelapa dan Frekuensi Penyemprotan Urin Sapi terhadap Pertumbuhan Bibit Pinang (Areca catechu L.). Savana Cendana, 2(01): 8-10.

Sugiyono 2006. Metode Penelitian Kuantitatif, Kualitatif dan $R \& D$. Bandung: Alfabeta.

Taena, W. 2009. Kajian Pengembangan Ekonomi Wilayah Perbatasan Kabupaten Timor Tengah Utara dengan District Enclave Oekusi. Tesis. Institut Pertanian Bogor. 